International Journal of Social Sciences and Humanities
Available online at http://sciencescholar.us/journal/index.php/ijssh
Vol. 1 No. 3, December 2017, pages: 74 87
e-ISSN: 2550-7001, p-ISSN: 2550-701X
http://dx.doi.org/10.21744/ijssh.v1i3.57

\title{
Opposition of Community Citizenship Against the Policy of the Village's Leader
}

I Nyoman Mardika a
Article history: Received 5 July 2017; Accepted in revised form 12 November 2017; Approved 28 November 2017;
Available online 11 December 2017

a Warmadewa University, Denpasar, Bali-Indonesia 
e-ISSN : 2550-7001, p-ISSN : 2550-701X@ Copyright 2017. The Author. SS Journals Published by Universidad Técnica de Manabí.

This is an open-access article under the CC BY-SA 4.0 license

(https://creativecommons.org/licenses/by-sa/4.0/)

All rights reserved.

\section{Contents}

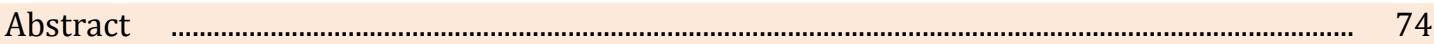

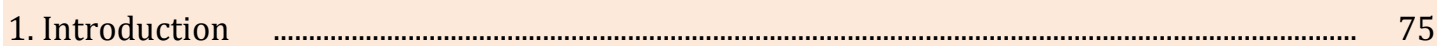

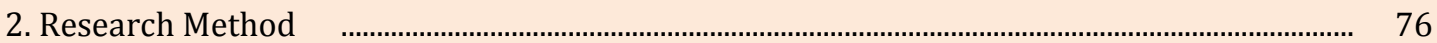

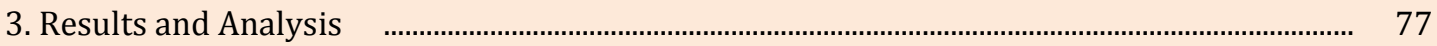

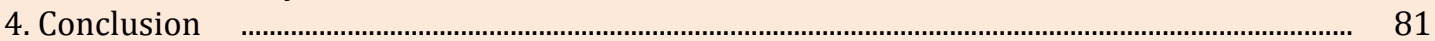

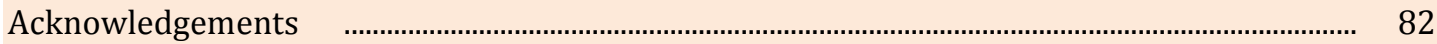

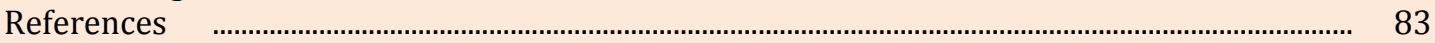

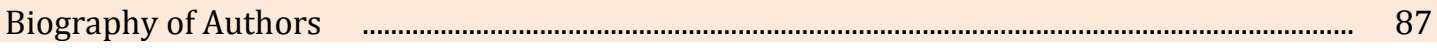

\section{Introduction}

In Bali, with the issuance of Provincial Regulation No. 3 of 2011 on Desa Pakraman (Desa Adat), Is affirmed that Desa Adat (Desa Pakraman) is a customary law community in Bali Province which has a unity of tradition and manners of community life Hindus people. Indigenous peoples in this area have existed for generations in the Khayangan Tiga or Khayangan Desa ties. The issuance of the local regulation ultimately led to the domination of traditional villages so that each customary village in this area has autonomous power for its own territory. Each adat village feels the need to enforce its rules (awig-awig) on its autonomous rights.

In carrying out the rules and autonomy rights, adat village has its own structure with its leader called Kelian Adat or Bendesa Adat accompanied by other (prajuru) officials. Adat leaders have the authority to adopt customary policies that are of course supported by citizens and in accordance with customary rules (awig-awig). However, in the policies taken klian adat not always run smoothly and sometimes get resistance (opposed) by its own citizens. Disputes between indigenous peoples are frequent and such disputes can become large when there is no space to communicate to find a way out. Even disputes between customary clans with their citizens to culminate in legal problems or spread to legal issues or green table as happened in the village of Perasi, District Karangasem, Karangasem regency Bali.

Actually, the terms and concepts about the Indigenous Villages in Bali are getting more familiar with the research conducted by foreign researchers such as Liefrinck who said that adat village is actually a small republic that has its own customary laws and rules. The structure of government is more democratic because every member (elder) has the same legal rights. The results of this Liefrinck study was legitimated V.E. Korn about villages in Bali that are autonomous. Korn who conducted a customary law study in Bali produced a book entitled Het Adatrecht van Bali (1932) which caused the village to be famous for its customary laws. From here finally comes the term custom village which means a village that has adat or traditional laws that become the guidelines of the village community. Thus the adat village is understood as a society that runs its rule autonomously, democratically, covering certain areas or boundaries, has a leader, rules (awig-awig), possesses wealth, and is hierarchically not under other higher powers 1 .

In its development, the existence of Balinese society today, especially indigenous peoples, will certainly not be equal to the Balinese indigenous peoples of the past or half a century ago. Previously, indigenous peoples in this area dominant is an agrarian society that most of its citizens live to farm. In many aspects of his life, indigenous peoples' lives are still relatively homogeneous with their harmonious and peaceful lifestyle and socially interpersonal manner.

Mardika, I. (2017). Opposition of Community Citizenship Against the Policy of the Village's Leader. International Journal Of Social Sciences And Humanities (IJSSH), 1(3), 74-87. doi:10.21744/ijssh.v1i3.57 
Traditional social organizations such as Subak, Desa Adat (Desa Pakraman), and Banjar are highly admired by outsiders because the social organization becomes a glue for the unity of society because of its strong customs. The society lives in harmony because it is based on Tri Hita Karana's philosophy of maintaining the relationship between man and God, a human family with human and man with the environment so as to reflect social-religious life.

Togetherness or kinship and brotherhood become the main principles that are held firmly in life by others. That sense of togetherness is manifested and reflected in the life of gotong-royong, please help in completing the work and the settlement in the form of consensus deliberation. With these views and principles, indigenous peoples in Bali expect a peaceful atmosphere, secure and kerta raharja (adequate). With the condition is not excessive if this area gets dubbed "Island of the Gods", "Pulau Seribu Pura", "Island of Heaven" and other nicknames.

However, in the development, due to the process of industrialization, reform and globalization have led to changes in people's lives such as livelihood, lifestyle and also the character of the Balinese themselves. Livelihoods that initially agriculture shifted to the tourism industry, productive lifestyles became consumptive and the way people's lives changed from collectivism to individualism and materialism. Changes of Balinese characters from previous hospitality and courteous in associating today tend to be violent and conflicted. Traditional institutions such as Desa Adat are social-religious and proud because they are capable of functioning to protect their citizens so that life is quiet and peaceful is no longer the case. However, Adat Village, which is a respected institution today, has often become a conflict arena to fight for various interests.

From the above description, there are two main issues to be studied in this paper, first why the villagers of Adat Perasi Village are fighting against their Adat leaders. What forms of sanctions are exchanged by citizens as a result of doing resistance and solutions that appear to end the conflict between society and their customary leaders?

\section{Research Method}

Some important concepts should be explained in this research to give direction in the research process is marginal villagers of adat Perasi village and opposition against the policy of the village's leader village. 
Road Research Map

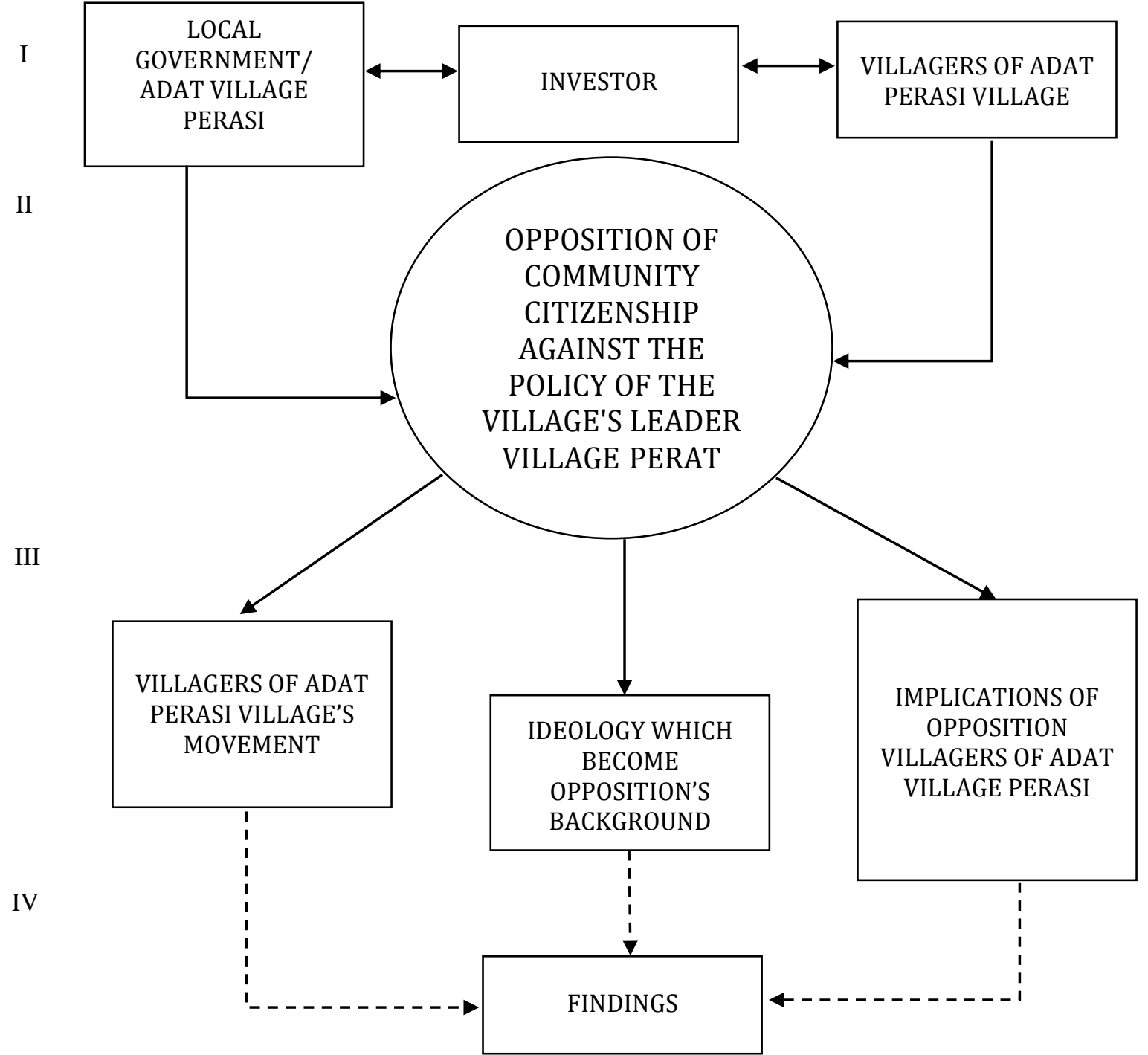

INFORMATION :

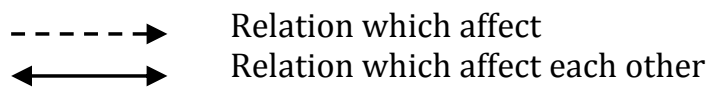

\section{Results and Analysis}

The process of change and the emergence of conflicts in the development of indigenous villages in Bali often occurs including in the area of Adat Village Perasi. In the field of livelihood, Perasi traditional villagers who originally lived from agriculture and fisher, have now changed because of a shift in livelihoods of life. Its citizens are no longer just dependent on agriculture and fishermen, but rather have been leading to services especially the tourism industry. This shift must have caused a change in the view of people's lives from the original emphasis on togetherness because the collectivity of citizens into commercialism (materialism) that leads to individuality. This is evident from the attitude of indigenous villagers that the land is willing to

Mardika, I. (2017). Opposition of Community Citizenship Against the Policy of the Village's Leader. International Journal Of Social Sciences And Humanities (IJSSH), 1(3), 74-87. doi:10.21744/ijssh.v1i3.57 
be contacted by investors, with the lure of getting a lot of money easily handed it. Including customary land (ulayat) called "temple profit" with easy land for rent, even with floating and potentially land status including the land of temple profit is lost or seized by the bank.

In fact, the ability of indigenous villages in Bali to maintain customs is generally considered relatively strong. Especially in maintaining and developing the customs and cultural values to be proud of, even been tested with almost every year held custom village races. However, on the other hand, the ability of customary villages to defend the right to control over property, especially in the form of land, especially customary land which in this case is an economic resource for the community, the ability of traditional village is said to be still weak.

The weak ability of indigenous villagers and their citizens to retain their right to control land, especially indigenous lands in Bali including in Desa Adat Perasi, Karangasem Bali is closely related to the values of togetherness and help to help and strengthen individual and commercial values. Adat leaders in Desa Adat Perasi who contracted village land (profit temple) actually contradict "Awig-Awig Desa Adat", causing conflict between indigenous people and adat leaders (adat clan). As a result, the attitude of citizens suspects and no longer prioritize togetherness in the interests of the traditional village itself. This is certainly contrary to the condition of traditional villages in the past half-century decade because of all the problems that occur in traditional villages easily solved politely and peacefully.

Long before a harmonious life with the philosophy of Tri Hita Karana, is certainly a glue for the integrity of indigenous peoples in Bali because the lives of its citizens are manifested in the form of a balance of life between man and God, between man and man and man and human beings with the environment that reflects the social-religious life . Citizens of society also make the concept of togetherness or kinship and fraternity be used as a basis for making decisions by consensus. This is reflected in the traditional village life of Perasi, which they originally lived with togetherness and brotherhood, but has changed since the development of tourism in the region.

Ideally, tourism development in a region including Indigenous Peoples territory of course with the aim for the welfare of the community so that people become peaceful and secure and prosperous. However, these hopes are off the mark because the real picture is happening, the tourism actually makes the people scattered happen in the village of Adat Perasi in the Village of Pertima, Karangasem District, Karangasem Regency from 2009 to 2013. There are 42 heads of household (KK) 650 households in Desa Adat Perasi who take a stand against the policy of Customary Claim (adat leaders) for not agreeing with the contract land contract process which is considered harmful by the community. The small group is fighting for the land belonging to the customary village (profit of the temple) by fighting to avoid the land belonging to Adat Village confiscated by the bank because it was appealed by the investor without a definite explanation. Investors woke up citizens' land including customary land because investors have paid 30 percent of the contract value land of contracted citizens. As a result, the attitude taken by aroup calling itself the Forum Warga Bersatu Desa Adat Perasi (Indonesian Adat Perasi Village) to conduct resistance, consequently they become marginalized because they have to accept the sanction ostracized (kasepekang).

Prior to the adat conflict, in fact from the narrative of groups or citizens who dared to take this opposite stance, they did not disagree that their land was leased to investors, let alone oppose and bring the matter to the realm of law. However, the local elite led by Wayan Reti Adnyana as Kelian not want to sit together to jointly discuss the issue of land contracts that are considered detrimental to the people, especially concerning land belonging to Adat Village called the land of temple profit. Kelian Adat with the attitude of arrogance just takes a stand against the people by giving sanctions against the group that defends the temple's earnings. The sanction was given to the group that opposed the contract of Adat Village with the investor and even then in the form of a customs sanction decision which was first received by a group of citizens named I Nengah Mudiarta which in essence temporary dismissal became Krama Adat Perasi which signed by Klian Adat Wyn. Reti Adnyana dated 21 July 2009. 
The sanction given against the people against it is considered as an act of arrogance because without going through an open and transparent process. Kelian adat considers residents who fight against the policies of traditional leaders who have negotiated with investors. Residents are considered to prevent the process of contracting contracts between customary leaders and investors through notaries. In fact, citizens who take the fight with the goal of rescuing customary land (profit temple) and it is in accordance with the awig-awig custom village. Precisely in the Awig-Awig Indigenous Village Perasi poured anyone including customary leaders can not take the policy that causes the customary land was lost as stated in Pawos 20 which says "Tan kalugra ngadol miwah ngadeang padruwen Traditional Village Perasi sejawening kagunayang manut petitis lan keraramin antuk krama Desa Adat Perasi, yan mamurug padruwen Adat Village, inucap kedaut tour kedanda seket kilo rice "(Awig-Awig Indigenous Village Perasi, 1989: 8-9). That is, residents are not allowed to sell or menggadekan land belonging to Customary Village Perasi. If there is a violation, then the concerned citizen will be subject to a fine of rice as much as $50 \mathrm{~kg}$ of rice.

Adat sanctions received by the citizens resulting from the resistance did not seem to discourage other colleagues from continuing to struggle to secure the profit of the temple even from the group dared to block the date of May 23, 2009 with the letter of notary Ida Bagus Mantara SH, Head of National Land Agency of Karangasem Regency and also the contract committee of PT Bias Putih from Perasi. They blocked the land of temple profit owned by Adat Village (Pakraman) Perasi as many as four certificates namely land rights property (HM) 1817 area of $1180 \mathrm{~m} 2$, land HM 1816 area of $730 \mathrm{~m} 2$, land HM 1818 area of $12080 \mathrm{~m} 2$ and land 5430 m2 HM 5430 area.

The purpose of 42 families is blocking the land of the temple, it does not mean that they are opposed to the decision of Adat Village to develop the area of Adat Village Perasi as a tourism area, let alone the development of tourism in the area have received support from the local government (Kabupaten Karangasem). However, blocking on the basis of consideration:

1. The contract system is not purely a contract, but a contract with the grant of Right to Build (HGB) on the Land of Property Rights.

2. There has never been any meeting or meeting between the community and the committee related to the extension of the lease in which there is an agreement on the provision of HGB over the Hak Hak Milik Land.

3. With the preliminary agreement of giving HGB above the Land of Property is really very detrimental to society and future generations, especially the unity of Adat Village (Pakraman) Perasi.

4. Agreement of giving HGB above Land of Property to this day has never been socialized to society.

5. The occurrence of turmoil in the meeting at Banjar Perasi Kelod Service on May 17, 2009, related four points above.

6. Measurements were taken from the National Land Agency measurement officer of Karangasem Regency in the field without the knowledge of the landowner.

7. Residents have sent SMS on May 19th and May 24th to Kelian Adat Perasi for a meeting but no response and follow-up.

With the seven points that are the basis of the group is not just solve the problem. However, the group that the adat leaders say is the minority is actually used as the basis to suppress them through customary sanction in the form of exclusion or kasepekang. After the sanction was granted to Nengah Mudiarta, Kelian Adat Wyn Reti Adnyana dated 31 August 2009 also issued a similar letter which is essentially the same ie the temporary discharge to Komang Genti became a citizen (Krama) Desa Adat Perasi.

Not only the two residents, Kelian Adat Perasi's peak actually gives consequences to all citizens (42 HHs) who do the blocking because his actions are considered to be guilty to the Institute of Customary Village / Contract Renewal Committee. The group of citizens who did the blocking was told to revoke the blocking support letter or make blocking letters that never aired

Mardika, I. (2017). Opposition of Community Citizenship Against the Policy of the Village's Leader. International Journal Of Social Sciences And Humanities (IJSSH), 1(3), 74-87. doi:10.21744/ijssh.v1i3.57 
otherwise never existed. Those who still did not heed the minutes of the meeting on the discussion of the blocking of land forbidding the temple of Indigenous Peoples Village, the 42 groups were given sanctions in the form of postponement of customary service, identical with a law ostracized or kasepekang. The courage of a handful of citizens who did the resistance because they move driven by the intellectuals of indigenous peoples who live in the city of Denpasar Perasi. This group of intellectuals does not necessarily have their Adat leaders who in implementing the policy arrogantly and dare to oppose the awig-awig of Adat Village. Kelian Adat is considered to have issued a policy that contracts a temple to violate awig-awig, but it is still done with its attitude of sanctioning against the opponents.

In addition to being pushed by an intellectual group, the 42 indigenous people are fighting for resistance because they still seem to respect the symbols in their village. There are half more groups of citizens who oppose this apparently its position is "Village of Murwa" or called their ancestor is the founder of Indigenous Village Perasi. As their symbol is a Desa Adat Murwa is in every meeting or paruman, they are equipped with a weapon become characteristic. In addition to the keris as a symbol, the villagers of Adat Perasi village who became the Indigenous Peoples of Murwa were also given a land by their ancestors called catu (inherited lands that were handed down from generation to generation) of approximately 14 acres. The symbols that exist in this part of the resistance are likely to encourage them to struggle to keep the temple's profit from falling into the hands of other people or investors who violate awig-awig.

This paper begins with a search for some of the literature or texts concerning the focus and location of the study undertaken as a new, unreleased study. Nevertheless, to support the results in accordance with the issues under consideration, it should be supported by several libraries to support in theories, ideas, concepts and information. In the context of the talk of Indigenous Peoples adat villagers that actually arise due to this tourism has never been done. However, some similar and relevant studies in this study can certainly be made a foothold in the related article "Adat and Sanki Kasepekang Conflicts in Indigenous Village Bungaya, Karangasem Regency, Bali: Perspective of Cultural Studies" by Wayan P Windia. Indigenous conflicts occurring in Desa Adat Bunga yes almost similar to what happened because the conflict caused the citizens to happen kesepekang. ${ }^{2}$ It's just the subsidy problem that happened in Desa Adat Bungaya with different Adat Perasi villages. If the conflict in Bungaya written Windia occurs because of differences in beliefs interpreting ancestral heritage, but in the village Adat Perasi because of the problem of customary land (profit of temples) due to the development of tourism. The conflicts occurring in Adat Bungaya village were more dominant due to internal factors, but in Perasi precisely because of internal problems in the community, also occurred due to external factors related to tourism development in Adat Perasi village. The next study is because in this paper it reveals the resistance of indigenous peoples to traditional leaders in this case the customary clan hence the relevant book become the foundation, "Desa Adat Menggugat dan Berugatat" from Prof, Dr. Tjok Istri Putra Astiti, SH, MH. Astiti elaborates, it must be recognized in the development process nowadays Balinese man has experienced a process that is so fast in line with the development of tourism itself. Balinese man previously known as agrarian culture developed into industrial culture (services). The classical process of spiritual culture is transformed into a commercial culture so that Balinese people undergo a vast commercialization process. There seems to be no limit to the rules of commercialization so that religion has indirectly become a commercially available material. Recent conflicts in Bali are the result of social change after the area has become a tourist area. For example, there is a conflict of interest in the utilization of natural resources (land, forest, water) between people who live in farming, with those who are engaged in tourism ${ }^{3}$. This view can be seen if there is coercion from the local elite in this case Kelian Adat with the accomplice in the village of Adat Perasi who let there is a land contract that at any time eliminate the existence of land (land) belonging to Adat Village called Laba Pura.Sedangkan foothold mass media used in this paper is used two local media in Bali that presents news related cases in Perasi that can no longer be solved through deliberation but the process on the green table (law). Kasepekang residents were forced to stay silent and reported Retny Adnyana who was accused of grabbing people's land. Klian Adatpun must deal 
with the citizens by taking a fight that is issuing the letter "kasepekang" to the citizens (Denpost, 29 April 2011 and Bali Post 25 April 2011). The case in Desa Adat Perasi has resulted in social and cultural conflicts in the community in the form of land acquisition process owned by residents and land belonging to Desa Adat which will be used as the development of tourism facilities and infrastructures. This concern also occurred during the emergence of tourism development policy in Desa Adat Perasi which is feared will cause the loss of land belonging to Desa Adat due to unclear contract agreement. Fortunately there are still a group of citizens or groups who care about the existence of temple profits so dare to fight by blocking the land of temple profit despite having to accept customary sanctions in the form of exclusion or kasepekang. The conflict between the people and the Adat leadership in Adat Village Perasi not only took place internally, but until it spread to the external and started with the activity of mutual reporting to the police station to seek legal justice. The legal process even took place not only in the police, but continued to spread to the hearing. However, my trial process has not reached the level, just a court decision that punishes Kleian Adat Perassi with a 7 month sentence, the conflict between the citizen and the leadership of Adat Persai changed. The reason, Kelian Adat Wayan Reti Adnyana who was undergoing the trial process, suddenly died suddenly so that residents who had been very hard to fight through the resistance, began to recede and reconciliation occurred. The reconciliation takes place because the villagers of Adat Perasi Village immediately do a paruman or meeting-repat to choose Kelian Adat to replace their adat clan. In this reconciliation it seems from the citizens who had time to fight, even their votes are accommodated with given one of the partners that Wayan Suwela to, go forward and appear as Vice Kelian Adat. While the elected into klian Adat is Wayan Gelgel who previously had become pengrajeg (figures) adat who participated in watching the previous adat Kelian. Even the form of reconsliation itself poured with the activities of Indigenous Peoples Perasi held a ceremony or religious ritual called Ngusaba Gunung. The ritual ceremony held once in three years becomes an important moment for the residents who previously kesepekang can do again with other residents so that reconciliation realized.

\section{Conclusion}

From the brief description above, it can be concluded that the emergence of citizen resistance in the Village Adat Perasi Subdistrict Karangasem because of the policy of the Adat leaders, in this case, Kelian or Bendesa Adat arrogant and its policy is contrary to the rules or Awig-awig Desa Adat. Customary Kelian should support the attitude of the citizens despite the amount that is not too much because dare to oppose the policy of Adat leadership is considered wrong. It is not just the contrary, those who have opposed the citizens are given an ostracized ban called "kepepekang" or isolated. The bravery of Indigenous Peoples Perasi conducts resistance against their Adat leaders because it is driven by two things, first because there are encouragement and motivation from the intellectual group Desa Adat Perasi who wander in outside like in Denpasar. Secondly, it appears that the symbols of Indigenous citizens who participated in the resistance also encouraged and caused them more daring to defend or nindihin belonging to Adat village i.e land of Profit temple. The shape of the symbol, the kris used every meeting or paruman and land supply is given by his ancestors to be handed down through generations. The villagers' resistance ended after the death of Adat Perasi clan that died suddenly so that there was a regeneration of customary leadership or chosen new adat Kelian. Even from the group that had done the resistance was given place to be the administrators of Adat Village by occupying important positions including representatives of adat Kelian. From the turn of the customary leader finally emerged called reconciliation so that the people who previously took the fight back were accepted as Indigenous Peoples. Even in the form of reconciliation made by Kelian Adat Perasi together with its citizens, they are performing a ritual ceremony called Ngusaba Gunung together.

Mardika, I. (2017). Opposition of Community Citizenship Against the Policy of the Village's Leader. International Journal Of Social Sciences And Humanities (IJSSH), 1(3), 74-87. doi:10.21744/ijssh.v1i3.57 


\section{Acknowledgement}

Thanks to Dean Of Sastra Faculty and Rector of Warmadewa University, also Chief of Cultural Studies of Udayana University and General Directorate of Education for support and role in my research. Writer as well says thanks to Villagers of Adat Perasi Village which helped in my research process. Hopefully, this writing which loaded in International Journal of Social Sciences and Humanities (IJSSH) that has meaningful meaning as the foundation of scientific, also information media for strengthening and development Adat Village in Bali especially Adat Perasi Village, Karangasem in-built local communication, national, and international. 


\section{References}

1. Pradnyaparamita DuarsaI, D., Ardika, W., Hakimi, M., \& Mariyah, E. The Perception Of The Teenagers of Premarital Sexual In Denpasar: Culture Studies Perspective. E-Journal of Cultural Studies, 4(1).

View in (Google Scholar)

2. Vickers, A., Prasetyo, A. B., \& Trisila, S. (2009). Peradaban pesisir: menuju sejarah budaya Asia Tenggara. Pustaka Larasan.

View in (Google Scholar)

3. Giddens, A., \& Kramadibrata, S. (1986). Kapitalisme dan teori sosial modern: suatu analisis terhadap karya-tulis Marx, Durkheim, dan Max Weber. Universitas Indonesia.

View in (Google Scholar)

4. Ardhana, I Ketut. FX Sunaryo, Sulandjari et al. 2011. Masyarakat Multikultural Bali : Tinjauan Sejarah, Migrasi dan Integrasi. Denpasar : Larasan dan Jurusan Sejarah Fakultas Sastra Universitas Udayana.

View in (Google)

5. Rahmawati, I. M. Seni lukis karya ni nyoman sani dalam dinamika seni lukis bali. View in (Google Scholar)

6. Sri Haryanti Dewi Witari, I., Wirta Griadhi, I. K., \& Oka Parwata, A. A. Sengketa tanah setra dan penyelesaiannya (studi kasus sengketa banjar adat ambengan dengan banjar adat semana ubud kabupaten gianyar). Kertha Desa, 1(02).

View in (Google Scholar)

7. Awig-Awig Desa Adat Perasi, Desa Pertima, Kecamatan Karangasem, Kabupaten Karangasem tahun 1989.

View in (Google Scholar)

8. Basyir, K. (2013). Pola Kerukunan Antarumat Islam dan Hindu di Denpasar Bali. ISLAMICA: Jurnal Studi Keislaman, 8(1), 1-27.

View in (Google Scholar)

9. Barker, Chris. 2005. Cultural Studies: Teori dan Praktik. Yogyakarta. Bentang. View in (Google Scholar)

10. Suacana, W. G. (2011). Budaya Demokrasi dalam Kehidupan Masyarakat Desa di Bali. Jurnal Kajian Bali (Journal of Bali Studies), 1(1).

View in (Google Scholar)

11. Dahrendorf, R. (1986). Konflik dan konflik dalam masyarakat industri: sebuah analisa-kritik. Penerbit CV Rajawali.

View in (Google Scholar)

12. LESMANA, H., \& AGAMA, J. P. Konstruksi Sosial-Budaya Dan Makna Air Suci Sendang Mbeji Padukuhan Parangrejo Girijati Purwosari Gunung Kidul Yogyakarta Bagi Para Peziarahnya. View in (Google Scholar)

Mardika, I. (2017). Opposition of Community Citizenship Against the Policy of the Village's Leader. International Journal Of Social Sciences And Humanities (IJSSH), 1(3), 74-87. doi:10.21744/ijssh.v1i3.57 
13. Geertz, C. (1983). Involusi Pertanian. Proses Perubahan Ekologi di Indonesia, 13-15.

View in (Google Scholar)

14. Geriya, I. W. (1995). Pariwisata dan dinamika kebudayaan lokal, nasional, global: bunga rampai antropologi pariwisata. Upada Sastra.

View in (Google Scholar)

15. Giddens, A., \& Kramadibrata, S. (1986). Kapitalisme dan teori sosial modern: suatu analisis terhadap karya-tulis Marx, Durkheim, dan Max Weber. Universitas Indonesia.

View in (Google Scholar)

16. Kumbara, A. N. A., Mbete, A. M., \& Mudanu, I. G. M. Resistance Of Katobengke Ethnic People To Hegemony Of Traditional Elites In Baubau City South East Sulawesi.

View in (Google Scholar)

17. Spillane, J. J. (1991). Ekonomi pariwisata: sejarah dan prosepeknya. Kanisius. View in (Google Scholar) (Scopus)

18. Mantra, I. B. (1992). Bali: masalah sosial budaya dan modernisasi. Upada Sastra. View in (Google Scholar)

19. Mantra, I. B. (1996). Landasan Kebudayaan Bali. Yayasan Dharma Sastra. View in (Google Scholar) (Scopus)

20. Monografi Desa Pertima, Kecamatan Karangasem, Kabupaten Karangasem 2009/2010Tahun 1999.

View in (Google)

21. Parimartha, I. G. (2011). Nilai karakter bangsa dan aktualisasinya dalam kehidupan masyarakat Bali. Udayana University Press.

View in (Google Scholar)

22. Parimartha, I. G. (2013). Silang pandang desa adat dan desa dinas di Bali. Udayana University Press.

View in (Google Scholar)

23. Pitana, I. G. (1994). Dinamika Masyarakat dan Kebudayaan Bali. Denpasar: Penerbit Bali Post.

View in (Google Scholar)

24. Sardiana, I. K., Windia, W. P., \& Sudantra, K. (2011). Peta desa: panduan mengelola konflik batas wilayah. Udayana University Press.

View in (Google Scholar)

25. Widiastini, N. M. A. (2013). Memenjor tradition, the contestation and implication to Hindu's community in Bali. Humaniora, 25(3), 237-248.

View in (Google Scholar)

26. Sumarta, I Ketut. (Peny). 2011. Himpunan Hasil-hasil Pesamuan Agung III Majelis Utama Desa Pakraman Bali. Denpasar : MDP Bali.

View in (Google Scholar) 
27. Surpha, I. W. (2002). Seputar desa pakraman dan adat Bali. Denpasar: Pustaka Bali Post. View in (Google Scholar)

28. Suryawan, I Ngurah. 2013. Kiri Bali "Sepilihan Esai Kajian Budaya". Yogyakarta : Kepel Press.

View in (Google)

29. Paramitha, A. A. I. C., \& Paramitha, A. A. I. C. (2016). Pelaksanaan Pemungutan Pajak Bea Perolehan Hak atas Tanah dan Bangunan (BPHTB) dalam Jual Beli Tanah dan Bangunan di Kabupaten Badung (Doctoral dissertation, Universitas Udayana).

View in (Google Scholar)

30. Windia Wayan, P, I Ketut Sudantra. 2008. Konflik Adat dan Sanksi Kasepekang di Desa Adat Bungaya, Kabupaten Karangasem, Bali : Perspektif Kajian Budaya, Disertasi S3 Kajian Budaya, UNUD, Denpasar.

View in (Google Scholar)

31. Hendrako, E. (2015). Hak waris anak perempuan terhadap harta peninggalan (studi kasus putusan ma ri no. 4766/pdt/1998). Lex privatum, 3(1).

View in (Google Scholar)

32. Amerta, I. M. S. (2017). The Role of Tourism Stakeholders at Jasri Tourism Village Development, Karangasem Regency. International Journal of Social Sciences and Humanities (IJSSH), 1(2), 20-28.

View in (Google Scholar)

33. Larantika, A. A. A. D., Zauhar, S., Makmur, M., \& Setyowati, E. (2017). Collaboration as a Strategy for Poverty Alleviation. International Journal of Social Sciences and Humanities (IJSSH), 1(3), 40-48.

View in (Google Scholar)

34. Aini, Z. (2017). The Actualization of cultural elements in novel Guru Onyeh by Salman Faris. International Journal of Social Sciences and Humanities (IJSSH), 1(3), 17-27.

View in (Google Scholar)

35. Cedeño, M. L. D., Arteaga, M. G. D., Pérez, A. V., \& Arteaga, M. L. D. (2017). Regulatory Framework for Renewable Energy Sources in Ecuador Case Study Province of Manabí. International Journal of Social Sciences and Humanities (IJSSH), 1(2), 29-42.

View in (Google Scholar)

36. Gámez, M. R., Pérez, A. V., Será, A. S., \& Ronquillo, Z. M. (2017). Renewable Energy Sources and Local Development. International Journal of Social Sciences and Humanities (IJSSH), 1(2), 10-19.

View in (Google Scholar)

37. Adetunji, A. T., Adetunji, A. V., Adeleke, E. O., \& Madubuike, S. C. (2017). Deregulation: The Effect of Market-led Approach to Nigerian Universities Management. International Journal of Social Sciences and Humanities (IJSSH), 1(1), 1-8.

View in (Google Scholar)

Mardika, I. (2017). Opposition of Community Citizenship Against the Policy of the Village's Leader. International Journal Of Social Sciences And Humanities (IJSSH), 1(3), 74-87. doi:10.21744/ijssh.v1i3.57 
38. Suparsa, I. N., Mantra, I. B. N., \& Widiastuti, I. A. M. S. (2017). Developing Learning Methods of Indonesian as a Foreign Language. International Journal of Social Sciences and Humanities (IJSSH), 1(2), 51-57.

View in (Google Scholar)

39. Nahak, S. (2017). Criminal Law Policy on Land Functions Impacting Climate Change in Indonesian National Law Perspective. International Journal of Social Sciences and Humanities (IJSSH), 1(3), 28-39.

View in (Google Scholar) 


\section{Biography of Author}

\begin{tabular}{|l|l|}
\hline & $\begin{array}{l}\text { Drs. I Nyoman Mardika, Msi., was born on 19th of December 1964 in Bali. } \\
\text { He is a senior lecturer at Faculty of Letters, Warmadewa University. He } \\
\text { has got his bachelor degree from the Faculty of "Sastra" Udayana } \\
\text { University and Finished his master in } 2000 \text { in Cultural Studies of Udayana } \\
\text { University. Now He is continuing his Doctor program in Cultural Studies } \\
\text { of Udayana University. Once, He was a Chief of Historical Study Program } \\
\text { and now as a Chief of the Cultural Studies of Warmadewa University. } \\
\text { Besides writing and doing research, as a lecturer, he has been trusted to } \\
\text { teach general basic courses of social science culture. He is actively doing } \\
\text { research in cooperated with Denpasar City Government focused on } \\
\text { Cultural Heritage In Denpasar City. Three studies have been finalized on } \\
\text { the Cultural Heritage in Denpasar City and effort for its preservation, } \\
\text { Archeology Perspective in 2007, Cultural Heritage in Denpasar City: } \\
\text { History Perspective in 2008, and Cultural Heritage in Denpasar City: } \\
\text { Urban Perspective in 2009. }\end{array}$ \\
\hline
\end{tabular}

Mardika, I. (2017). Opposition of Community Citizenship Against the Policy of the Village's Leader. International Journal Of Social Sciences And Humanities (IJSSH), 1(3), 74-87. doi:10.21744/ijssh.v1i3.57 